\title{
SWOT ANALYSIS AND TOWN MATRIX E-GOVERNMENT ON TANA TIDUNG CITY OF KALIMANTAN UTARA
}

\author{
Rudy $^{1} \&$ Abdul Muis Prasetia ${ }^{2}$ \\ ${ }^{1,2}$ Universitas Borneo Tarakan \\ E-mail: rudy232@borneo.ac.id
}

\begin{abstract}
Information and Communication Technology (ICT) can improve the speed of information delivery, efficiency, global reach and transparency. One of the efforts to realize good corporate governance (GCG) governance in the era of regional autonomy is to use information and communication technology or popularly called e-Government. The implementation of e-Government the need for master plan information technology as a guide in the integration of information technology in Local Government, e-Government implementation is expected to help improve interaction between government, community and business, so as to encourage political and economic development. In this paper presents the determination of e-Government policy strategy using SWOT analysis method which is considered capable to analyze the relationship or interaction between internal elements, namely strengths and weaknesses, as well as against the external elements of opportunities and threats. The results of the analysis are: (1) The use of SWOT Analysis and Ideal Service Matrix in e-Government Policy Plan in local government is expected to give maximum support to accountability and transparency of bureaucracy towards Good Corporate Government; (2) This research resulted in the analysis of the preparation of e-Government master plan on the Regional Government of Tana Tidung Regency; and (3) A plan to utilize information technology in terms of marketing, production, product development and finance can be made. These results can be followed up with the use of information technology containing SWOT analysis in the development of e-Government in the Regional Government of Tana Tidung Regency.
\end{abstract}

Keywords: ICT, SWOT, e-Government

\section{ABSTRAK}

Teknologi Informasi dan Komunikasi (TIK) dapat meningkatkan kecepatan penyampaian informasi, efisiensi, jangkauan global dan transparansi. Salah satu upaya untuk mewujudkan pemerintahan yang good corporate governance (GCG) pada era otonomi daerah adalah menggunakan teknologi informasi dan komunikasi atau yang popular disebut dengan e-Government. Dalam implementasi e-Government tersebut perlu adanya rencana induk teknologi informasi sebagai pedoman dalam integrasi teknologi informasi di Pemerintah Daerah, implementasi e-Government diharapkan dapat membantu meningkatkan interaksi antara pemerintah, masyarakat dan bisnis, sehingga mampu mendorong perkembangan politik dan ekonomi. Dalam makalah ini menyajikan penentuan strategi kebijakan e-Government menggunakan metode analisis SWOT yang dipandang mampu untuk menganalisis hubungan atau interaksi antara unsur-unsur internal, yaitu kekuatan dan kelemahan, serta terhadap unsur-unsur eksternal yaitu peluang dan ancaman. Hasil analisis yaitu: (1) penggunaan Analisa SWOT dan Matriks Layanan Ideal dalam Rancangan Kebijakan e-Government di pemerintah daerah diharapkan mampu memberikan dukungan maksimal terhadap akuntabilitas dan transparansi birokrasi menuju Good Corporate Government; (2) penelitian ini menghasilkan analisis penyusunan rencana induk e-Government pada Pemerintahan Daerah Kabupaten Tana Tidung; dan (3) dapat dilakukan rencana pemanfaatan teknologi informasi dari segi pemasaran, produksi, pengembangan produk, dan keuangan. Hasil ini dapat ditindaklanjuti dengan penggunaan teknologi informasi memuat analisa SWOT dalam pengembangan e-Government pada Pemerintahan Daerah Kabupaten Tana Tidung.

Kata kunci: TIK, SWOT, e-Government

\section{PENDAHULUAN}

Dewasa ini, Teknologi informasi dan komunikasi (TIK) berkembang sangat cepat sehingga mampu membawa perubahan disegala bidang kehidupan, terutama pada kapasitas kerja dan usaha. TIK mampu menghilangkan jarak dan sekat waktu, serta arus informasi yang mengalir sangat cepat, sehingga proses globalisasi menjadi lebih cepat terwujud. Pada akhirnya menjadi tidak terbendung dan mampu merubah paradigma 
ekonomi, budaya, sosial dan masyarakat. TIK tidak hanya mengeser paradigma infrastruktur umum, namun telah disepakati sebagai infrastruktur masyarakat era milenium dalam mendorong lahirnya keadilan karena setiap orang terjamin kesetaraan dalam akses informasi, akses pelayanan disamping akses kecepatan transaksi ${ }^{(1)}$.

Selain itu, perubahan kebijakan ekonomi saat ini telah mengalami pergeseran dari ekonomi yang bertumpu pada kebijakan fiskal kearah kebijakan berbasis teknologi dan manajemen yang bersintesa dengan kapitalisme finansial, dimana pendorong utama globalisasi ini adalah Teknologi Informasi dan Komunikasi. Dengan basis masyarakat berpengetahuan ekonomi global, dimana sentra-sentra produksi pertanian diorganisir dalam jaringan perdagangan berbasis TIK sehingga terbentuk pasar lokal, nasional maupun global. Pengembangan lebih lanjut dapat menggunakan sistem ekonomi sosialisme modern berbasis TIK, dimana rakyat sebagai partisipan aktif dalam dunia usaha. Kedepan kekuatan ekonomi haruslah bertumpu dengan sebanyak mungkin korporasi kecil, sehingga SDM perlu dimotivasi ke arah enterpreuneur/pengusaha pertanian rakyat ${ }^{(2)}$.

Undang-Undang Tentang Informasi dan Transaksi Elektronik (ITE) No 11 Tahun 2008 menjamin bahwa transaksi elektronik telah memiliki payung hukum yang jelas (3). Pemerintah Indonesia telah melindungi terhadap hak dan kewajiban dalam melakukan transaksi elektronik sehingga sehingga keamanan data dan transaksinya terjamin. Implementasi e-Government semakin jelas dari pasal 4 butir C UU ITE yang menyebutkan bahwa pemanfaatan teknologi informasi dan transaksi elektronik dilaksanakan dengan tujuan untuk meningkatkan efektifitas dan efisiensi pelayanan publik $^{(3)}$.

Penggunaan TIK di lingkungan pemerintahan dalam rangka meningkatkan kualitas layanan publik secara efektif dan efisien dikenal dengan sebutan e-Government. Instruksi Presiden No. 3 Tahun 2003 tentang Kebijakan dan Strategi Nasional Pengembangan e-Government ${ }^{(4)}$. Dimana setiap Gubernur dan Bupati/Walikota diamanatkan untuk mengambil langkahlangkah yang diperlukan sesuai dengan tugas, fungsi dan kewenangan masing-masing guna terlaksananya pengembangan e-Government secara nasional ${ }^{(5)}$.

Sejalan dengan telah diberlakukan kebijakan otonomi daerah serta dimulainya sistem perdagangan bebas, maka setiap pemerintah daerah dituntut untuk menyediakan berbagai sarana dan prasarana untuk mendukung kinerja pemerintah daerah tersebut baik secara operasional maupun pada tingkat pengambilan keputusan. Salah satu sarana utama tersebut adalah kemampuan untuk menyimpan, menyediakan, dan mengelola data menjadi informasi yang tepat dan akurat serta adanya kemudahan dalam mendapatkan serta mendistribusikan data dan informasi tersebut.

Organisasi Pemerintah Kabupaten Tana Tidung yang mempunyai tugas untuk mengakumulasi data dan informasi dari beberapa Satuan Kerja Perangkat Daerah (SKPD) dibawah koordinasinya, harus saling kerjasama khususnya dalam pertukaran data/informasi untuk mendukung pembuatan suatu kebijakan atau keputusan yang akurat di lingkungan Pemerintah Kabupaten Tana Tidung. Untuk itu pemanfaatan TIK harus mempunyai suatu acuan perencanaan pengembangan infrastruktur e-Government yang terstruktur dan berkesinambungan, tidak hanya dari segi penggunaan teknologi akan tetapi harus dibarengi dengan pengembangan kapasitas sumber daya manusia. serta prosedur-prosedur yang diperlukan untuk menjalankan dan memanfaatkan infrastruktur teknologi informasi tersebut.

Jika hal ini tidak dilakukan, dimungkinkan bisa terjadi suatu distorsi dimana masing-masing SKPD seperti Dinas, Badan, Biro, dan Kantor di lingkungan Pemerintah Kabupaten Tana Tidung melakukan perencanaan masing-masing yang saling tumpang tindih atau mungkin saling 
tidak terhubung satu sama lainnya baik dalam penyediaan infrastruktur teknologi, sumber daya manusia serta prosedur-prosedur dalam pemanfaatan TIK. Disamping itu, kebijakan pemanfaatan TIK yang berjalan sendiri-sendiri seringkali membuat pemborosan investasi yang berakibat pada pembengkakan anggaran terkait penyediaan infrastruktur teknologi informasi dan perangkat penunjang lainnya.

Untuk menghindari hal-hal yang telah disebutkan di atas perlu disusun acuan yang baku dalam merekomendasikan perencanaan, penerapan dan pemanfaatan TIK di Pemerintah Kabupaten Tana Tidung dengan penerapan anilisa SWOT.

\section{METODE}

Pembahasan pada sub bab ini terbagi menjadi analisis SWOT dan TIK Kabupaten Tana Tidung. Analisis SWOT adalah identifikasi berbagai faktor secara sistematis untuk merumuskan strategi Perusahaan ${ }^{(6)}$. Analisis SWOT mempunyai peranan penting dalam kemajuan usaha yang akhir-akhir ini semakin kompetitif persaingannya dalam mencapai tujuan. SWOT merupakan Strengths, Weakness, Opportunity, and Threats. Yang mempunyai arti Kekuatan, Kelemahan, Peluang, dan Ancaman.

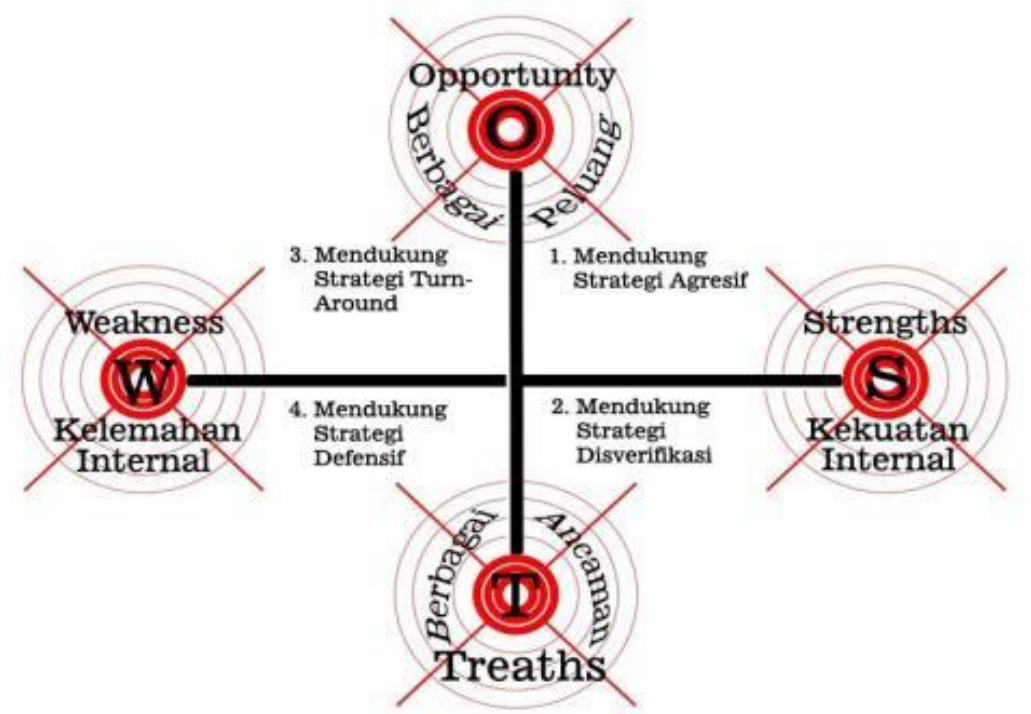

Gambar : Analisis SWOT $^{(7)}$

Peluang (Opportunities) Suatu peluang merupakan situasi utama yang mengguntungkan dalam lingkungan perusahaan. Kecenderungan kecenderungan utama ini adalah salah satu peluang identifikasi dari segmen pasar yang sebelumnya terlewatkan, perubahanperubahan dalam keadaan bersaing, atau peraturan, hubungan pembeli, perubahan teknologi dan hubungan pembeli dan pemasok yang telah diperbaiki dapat menunjukan peluang bagi perusahaan ${ }^{(7)}$.

Ancaman (Threathment) Ancaman adalah rintanganrintangan utama bagi posisi sekarang atau yang diinginkan dari perusahaan. Masuknya pesaing baru, pertumbuhan pasar yang lambat, daya tawar pembeli dan pemasok utama yang meningkat, perubahan teknologi, dan peraturan yang baru atau yang direvisi dapat merupakan ancaman bagi keberhasilan suatu perusahaan ${ }^{(7)}$.

Kekuatan (Strongth) Kekuatan adalah sumber daya, ketrampilan atau keunggulan lain yang relatif terhadap pesaing dan kebutuhan dari pasar suatu perusahaan layani atau hendak layani. Kekuatan merupakan suatu kompetensi yang berbeda (destintive competence) yang memberperusahaan suatu keunggulan komparatif (comparative advantage) dalam pasar. Kekuatan berkaitan dengan sumber daya, keuangan, citra, 
kepemimpinan pasar, hubungan pembeli/pemasok, dan faktor-faktor lain ${ }^{(7)}$.

Kelemahan (Weakness) Kelemahan merupakan keterbatasan/kekurangan dalam sumber daya, ketrampilan, dan kemampuan yang secara seerius menghalangi kinerja efektif suatu perusahaan. Dari pembahasan diatas analisis SWOT merupakan instrumen yang ampuh dalam melakukan analisis strategi. Keampuhan tersebut terletak pada kemampuan para penentu strategi perusahaan untuk memaksimalkan peranan faktor kekuatan dan pemanfaatan peluang sehingga sekaligus berperan sebagai alat untuk meminimalisasi kelemahan yang terdapat dalam tubuh organisasi dan menekan dampak ancaman yang timbul dan harus dihadapi ${ }^{(7)}$.

Tahapan penelitian dibagi menjadi 4 bingkai dasar, yaitu Input, analisa, proses, dan hasil. Pada tahapan input, dilakukan pengumpulan data melalui servey yang berkaitan dengan proses dan penggunaan TIK yang sedang berjalan di SKPD tersebut, sehingga dapat mengetahui permasalahan yang terjadi.

Analisa dilakukan untuk evaluasi penggunaan TIK saat ini, evaluasi ini dilakukan dengan analisa SWOT. Proses dikerjakan sebelum menyusun matrik SWOT yang terlebih dahulu disusun analisis internal dan analisis eksternal. Hasil dilakukan rencana pemanfaatan teknologi informasi dari semua bidang.

Analisis SWOT yang disusun merupakan hasil dari survey langsung terhadap instansi pemerintah Kabupaten Tana Tidung, dan juga hasil dari survey terhadap dokumen-dokumen pendukung (data sekunder) yang terdapat di Pemerintah Kabupaten Tana Tidung.

Pemerintahan Kabupaten Tana Tidung saat ini masih belum memiliki badan atau unit kerja yang mempunyai tanggung jawab dibidang teknologi informasi dan komunikasi, sehingga hal-hal terkait perumusan kebijakan teknis dalam bidang TIK, penyusunan rencana dan evaluasi program pembangunan dibidang TIK, dan pengembangan sistem informasi pemerintah daerah, serta pembinaan kelembagaan bidang TIK yang seakan masih berjalan sendiri-sendiri dan tidak berjalan secara optimal. Untuk SDM baik PNS dan non PNS di lingkungan SKPD Kabupaten Tana Tidung sebagian besar telah mampu menggunakan fasilitas TIK dan memanfaatkan internet.

Tidak semua SKPD memiliki instalasi LAN untuk menghubungkan perangkat TIK dan kebutuhan LAN belum menjadi prioritas di tiap-tiap SKPD. Kemudian SKPD yang memiliki LAN, tetapi tidak memiliki akses internet adalah Kantor Pemberdayaan Masyarakat dan Pemdes, dan Dinas Kependudukan dan Pencatatan Sipil. Sisanya, SKPD yang tidak memiliki instalasi LAN maupun akses internet.

\section{HASIL DAN PEMBAHASAN}

Dari analisis ini maka dapat dilakukan evaluasi diri untuk berbenah diri membangun sistem e-Government yang handal dan terpadu. Selain itu, dengan analisis SWOT tersebut dapat diidentifikasi beberapa masalah utama yang perlu mendapatkan perhatian untuk dapat mencapai kondisi yang memungkinkan untuk membangun dan mengembangkan e-Government. Strategi pengembangan e-Government menurut prioritas selanjutnya dapat dibangun berdasarkan analisis SWOT yang telah disusun, disesuaikan dengan kondisi yang ada di Pemerintah Kabupaten Tana Tidung. Analisis lingkungan Stratejik yang dilakukan melalui analisis lingkungan internal (ALI) dan analisis lingkungan eksternal (ALE). ALI dilakukan melalui pencermatan lingkungan internal organisasi, sedangkan ALE dilakukan melalui pencermatan lingkungan ekternal organisasi. Hasil identifikasi SWOT dapat disajikan pada Tabel 1 . 
Tabel 1. Identifikasi faktor SWOT

\begin{tabular}{|c|c|c|c|}
\hline \multicolumn{2}{|c|}{ ALE } & \multicolumn{2}{|c|}{ ALI } \\
\hline Kekuatan (S) & Kelemahan (W) & Peluang (O) & Tantangan $(\mathrm{T})$ \\
\hline $\begin{array}{l}\text { 1. Pimpinan memiliki } e \text { - } \\
\text { leadership; } \\
\text { 2. Ketersediaan S/W, } \\
\text { H/W dan jaringan yang } \\
\text { cukup; } \\
\text { 3. Ketersediaan akses } \\
\text { internet memadai; } \\
\text { 4. Pendanaan untuk } \\
\text { peningkatan Kapasitas } \\
\text { SDM tersedia; } \\
\text { 5. Adanya pembinaan } \\
\text { dan pendampingan } \\
\text { dari pemerintah pusat } \\
\text { terkait pengembangan } \\
\text { e-Government. }\end{array}$ & $\begin{array}{l}\text { 1. SDM yang menguasai dan } \\
\text { memanfaatkan TIK masih } \\
\text { rendah dan belum merata } \\
\text { 2. Pengembangan } \mathrm{S} / \mathrm{W}, \mathrm{H} / \mathrm{W} \\
\text { serta pengelolaan data } \\
\text { belum terintegrasi dan } \\
\text { terpadu } \\
\text { 3. Perlu waktu yang lama } \\
\text { untuk mendapatkan } \\
\text { informasi online yang up } \\
\text { to date } \\
\text { 4. Kesenjangan akses } \\
\text { informasi antara } \\
\text { pemerintah dan } \\
\text { masyarakat }\end{array}$ & $\begin{array}{l}\text { 1. Perangkat TIK } \\
\text { cenderung murah, } \\
\text { open source dan } \\
\text { mudah digunakan. } \\
\text { 2. Media akses } \\
\text { internet sangat } \\
\text { bervariasi dan } \\
\text { terjangkau bagi } \\
\text { seluruh lokasi di } \\
\text { Indonesia. } \\
\text { 3. Materi } \\
\text { pembelajaran di } \\
\text { bidang TIK sangat } \\
\text { mudah diperoleh } \\
\text { secara free. }\end{array}$ & $\begin{array}{l}\text { 1. Konvergensi } \\
\text { teknologi informasi } \\
\text { untuk komunikasi } \\
\text { data, suara dan } \\
\text { video sangat cepat } \\
\text { 2. Tuntutan } \\
\text { masyarakat untuk } \\
\text { mendapatkan data } \\
\text { dan informasi yang } \\
\text { cepat, tepat, } \\
\text { terpadu, dan akurat. } \\
\text { 3. Kondisi geografis } \\
\text { menyebabkan } \\
\text { kesenjangan } \\
\text { informasi }\end{array}$ \\
\hline
\end{tabular}

Setelah mengidentifikasi faktor-faktor SWOT (Strongth, Weakness, Opportunities, Threathment), analisis selanjutnya menyusun Matrik SWOT yang tersaji pada Tabel 2. Matriks SWOT adalah alat untuk menyusun faktor-faktor strategis organisasi yang dapat menggambarkan secara jelas bagaimana peluang dan ancaman eksternal yang dihadapi organisasi dapat disesuaikan dengan kekuatan dan kelemahan yang dimilikinya.

Tabel 2. Analisis SWOT Kebijakan E-Government

\begin{tabular}{|c|c|}
\hline $\begin{array}{l}\text { Strategi menggunakan kekuatan untuk } \\
\text { memanfaatkan peluang }\end{array}$ & $\begin{array}{l}\text { Strategi mengatasi kelemahan dengan } \\
\text { memanfaatkan peluang }\end{array}$ \\
\hline $\begin{array}{l}\text { 1. Manfaatkan e-leadership untuk optimalisasi } \\
\text { pendayagunaan sumber daya TIK yang sudah } \\
\text { ada. } \\
\text { 2. Meningkatkan komunikasi interaktif dengan } \\
\text { dunia usaha kecil dan menengah untuk } \\
\text { meningkatkan ekonomi rakyat } \\
\text { 3. Optimalkan konsultansi dengan instansi } \\
\text { pemerintah yang berkompeten dengan } e \text { - } \\
\text { Government untuk mempercepat implementasi } e \text { - } \\
\text { Government }\end{array}$ & $\begin{array}{l}\text { 1. Manfaatkan e-leadership pimpinan untuk } \\
\text { efisiensi biaya komunikasi dan proses kerja. } \\
\text { 2. Manfaatkan Internet untuk meningkatkan } \\
\text { kapasitas SDM dan kemandirian mengelola } \\
\text { sumber daya TIK } \\
\text { 3. Manfaatkan ketersediaan S/W, H/W dan } \\
\text { jaringan untuk ketersediaan informasi yang } \\
\text { cepat dan akurat } \\
\text { 4. Manfaatkan kemitraan dengan instansi } \\
\text { pemerintah yang berkompeten di bidang TIK. }\end{array}$ \\
\hline $\begin{array}{c}\text { Strategi menggunakan kekuatan untuk } \\
\text { menghadapi tantangan }\end{array}$ & $\begin{array}{l}\text { Strategi mengatasi kelemahan untuk } \\
\text { menghadapi tantangan }\end{array}$ \\
\hline $\begin{array}{l}\text { 1. Tingkatkan kemampuan SDM yang terampil } \\
\text { dalam penggunaan teknologi informasi untuk } \\
\text { mengefektifkan pelayanan kepada masyarakat } \\
\text { 2. Manfaatkan internet sebagai sumber pengetahuan } \\
\text { yang melimpah. }\end{array}$ & $\begin{array}{l}\text { 1. Meningkatkan kapasitas SDM di bidang TIK } \\
\text { dan sikap melayani masyarakat. } \\
\text { 2. Realokasi penempatan SDM di tempat yang } \\
\text { tepat untuk antisipasi perkembangan teknologi } \\
\text { informasi yang sangat cepat }\end{array}$ \\
\hline $\begin{array}{l}\text { 3. Meningkatkan koordinasi antar SKPD dan } \\
\text { antar kecamatan dalam lingkup Kabupaten, } \\
\text { Provinsi dan Pemerintah Pusat } \\
\text { 4. Memfasilitasi masyarakat dengan akses dan } \\
\text { informasi secara merata di seluruh wilayah. }\end{array}$ & $\begin{array}{l}\text { 3. Lakukan Reengineering proses kerja untuk } \\
\text { pelayanan terbaik bagi masyarakat } \\
\text { 4. Fasilitasi masyarakat desa dengan akses } \\
\text { Informasi } \\
\text { 5. Mengajak partisipasi masyarakat dalam } \\
\text { penyusunan grand design }\end{array}$ \\
\hline
\end{tabular}


Dengan mempertimbangkan kondisi $e$ Government di pemerintah daerah saat ini serta memperhatikan hasil kajian SWOT, pencapaian strategis e-Government perlu dilaksanakan melalui 5 (enam) strategi yang berkaitan erat, yaitu: (1) Menguatkan kebjiakan pembangunan e-Government melalui pembuatan payung hukum yang mengatur tentang pelaksanaan e-Government di pemerintah daerah; (2) Memanfaatkan teknologi informasi secara optimal untuk layanan e-Government Pemerintahan maupun publik; (3) Meningkatkan peran serta dunia usaha dan mengembangkan industri telekomunikasi dan teknologi informasi; (4) Mengembangkan kapasitas SDM; dan (5) Melaksanakan pengembangan secara sistematik melalui tahapan-tahapan yang realistik dan terukur.

\section{SIMPULAN}

Berdasarkan dari penelitian yang telah dilaksanakan dan sudah diuraikan dalam analisis SWOT guna penyusunan rencana induk e-Government pada Pemerintahan Daerah Kabupaten Tana Tidung sebagai berikut: (1) Penggunaan Analisa SWOT dan Matriks Layanan Ideal dalam Rancangan Kebijakan e-Government di pemerintah daerah diharapkan mampu memberikan dukungan maksimal terhadap akuntabilitas dan transparansi birokrasi menuju Good Corporate Government; (2) Penelitian ini menghasilkan analisis penyusunan rencana induk $e$ Government pada Pemerintahan Daerah Kabupaten Tana Tidung; dan (3) Dapat dilakukan rencana pemanfaatan teknologi informasi dari segi pemasaran, produksi, pengembangan produk, dan keuangan. Hasil ini dapat ditindaklanjuti dengan penggunaan teknologi informasi memuat analisa SWOT dalam pengembangan e-Government pada Pemerintahan Daerah Kabupaten Tana Tidung.

\section{REFERENSI}

[1] Supriyanto, W. \& Muhsin, A. Teknologi Informasi Perpustakaan. Yogyakarta: Kanisius, 2008.

[2] Habibullah, Achmad. Kajian Pemanfaatan dan Pengembangan eGovernment. 3, 2010, Masyarakat, Kebudayaan dan Politik, Vol. 23, 187195. ISSN 2086-7050.

[3] Indonesia, Republik. UU Nomor 11 Tahun 2008 Tentang Informasi dan Transaksi Elektronik. Lembaran Negara RI Tahun 2008 No, 58. Jakarta : Sekretariat Negara, 2008.

[4] Indonesia, Republik. Instruksi Presiden tentang Kebijakan dan Strategi Nasional Pengembangan eGovernment, No. 3 Tahun 2003. Jakarta : Deputi Sekretaris Kabinet Bidang Hukum dan Perundangundangan, 2003.

[5] Grant, Gerald \& Chau, Derek. Developing a Generic Framework for E-Government. 1, 2005, Journal of Global Information Management, Vol. 13, 1-30.

[6] Khaira, Z. Pengembangan Website BKD Karanganyar untuk Meningkatkan Kualitas Penyediaan Informasi Kepegawaian. Yogyakarta: Sekolah Tinggi Multi Media, 2010.

[7] Pearce, J. A. \& Robinson, R. B. Strategic Management: Formulation, Implementation, and control. New York : McGraw-Hill/Irwin, 2008. 